\title{
The Utilization of the Microflora Indigenous to and Present in Oil-Bearing Formations to Selectively Plug the More Porous Zones Thereby Increasing Oil Recovery During Waterflooding
}

\author{
Quarterly Report \\ January 1 - March 31,, 1998
}

\author{
By: \\ Lewis R. Brown; Alex A. Vadie
}

Work Performed Under Contract No.: DE-FC22-94BC14962

For

U.S. Department of Energy

Office of Fossil Energy

Federal Energy Technology Center

P.O. Box 880

Morgantown, West Virginia 26507-0880

By

Hughes Eastern Corporation

Mtel Centre South Building

200 South Lamar Street, Suite 1050

Jackson, Mississippi 39201 


\section{Disclaimer}

This report was prepared as an account of work sponsored by an agency of the United States Government. Neither the United States Government nor any agency thereof, nor any of their employees, makes any warranty, express or implied, or assumes any legal liability or responsibility for the accuracy, completeness, or usefulness of any information, apparatus, product, or process disclosed, or represents that its use would not infringe privately owned rights. Reference herein to any specific commercial product, process, or service by trade

name, trademark, manufacturer, or otherwise does not necessarily constitute or imply its endorsement, recommendation, or favoring by the United States Government or any agency thereof. The views and opinions of authors expressed herein do not necessarily state or reflect those of the United States Government or any agency thereof. 


\section{SEVENTEENTH QUARTERLY PROGRESS REPORT}

TITLE:

THE UTILIZATION OF THE MICROFLORA INDIGENOUS TO AND PRESENT IN OIL-BEARING FORMATIONS TO SELECTIVELY PLUG THE MORE POROUS ZONES THEREBY INCREASING OIL RECOVERY DURING WATERFLOODING

\section{COOPERATIVE AGREEMENT NUMBER:}

DE-FC22-94BC14962

\section{RECIPIENT:}

Hughes Eastern Corporation

Mtel Centre South Building

200 South Lamar Street, Suite 1050

Jackson, MS 39201

\section{DATE OF REPORT:}

April 20, 1998

\section{AWARD DATE:}

January 1, 1994

ANTICIPATED COMPLETION DATE:

June 30, 1999

\section{GOVERNMENT AWARD:}

$\$ 239,158$ (Current Year DOE Share)

\section{PROGRAM MANAGER:}

James O. Stephens

Hughes Eastern Corporation

PRINCIPAL INVESTIGATORS:

Lewis R. Brown

Mississippi State University

Alex A. Vadie

Mississippi State University

CONTRACTING OFFICER'S REPRESENTATIVE:

Martin J. Byrnes (412) 892-4486

U.S. Department of Energy

Federal Energy Technology Center

P.O. Box 10940 MS 921-118

Pittsburgh, PA 15236-0940

\section{DOE PROJECT OFFICER:}

Rhonda P. Lindsey

National Petroleum Technology Office

Post Office Box 3628

Tulsa, OK 74101

\section{REPORTING PERIOD:}

January 1, 1998 - March 31, 1998 


\section{SEVENTEENTH QUARTERLY PROGRESS REPORT}

\section{OBJECTIVE}

The objective of this work is to demonstrate the use of indigenous microbes as a method of profile control in waterfloods. It is expected that as the microbial population is induced to increase, that the expanded biomass will selectively block the more permeable zones of the reservoir thereby forcing injection water to flow through the less permeable zones which will result in improved sweep efficiency.

This increase in microbial population will be accomplished by injecting a nutrient solution into four injectors. Four other injectors will act as control wells. During Phase I, two wells will be cored through the zone of interest. The core will be subjected to special core analyses in order to arrive at the optimum nutrient formulation. During Phase II, nutrient injection will begin, the results monitored, and adjustments to the nutrient composition made, if necessary. Phase II also will include the drilling of three wells for post-mortem core analysis. Phase III will focus on technology transfer of the results. It should be pointed out that one expected outcome of this new technology will be a prolongation of economical waterflooding operations, i.e. economical oil recovery should continue for much longer periods in the producing wells subjected to this selective plugging technique. Results from work under DOE Contract No. DE-AC22-90BC14665 will be incorporated as appropriate.

\section{SUMMARY OF TECHNICAL PROGRESS}

\section{Phase I. Planning and Analysis}

The concepts for the new technology to be evaluated in this project are scientifically sound and have been proven to be effective in laboratory experiments. Nevertheless, it is necessary to perform laboratory tests on live cores from the reservoir of interest. Two wells will be drilled for this purpose and special core analyses will be conducted in order to fine tune the exact concentration of, and schedule for, additions of nutrients to the injection water.

While the main purpose for drilling the two wells is to obtain cores suitable for use in the laboratory work, a secondary purpose is to obtain production data which will indicate the sweep efficiency of the existing waterflood. At the conclusion of Phase I, a specific feeding regime will have been formulated for each of the injection wells. Since the injection wells all vary in terms of years of service, differences in channeling are anticipated and a different feeding regime may be needed for each well.

The work for Phase I of the project has been divided into seven tasks as described below.

Task 1.1: The Drilling of Two New Injection Wells for the Acquisition of Cores and Other Data.

$$
\text { Completed }
$$

Task 1.2: $\quad$ On-Site Handling of Cores

Completed.

Task 1.3: $\quad$ Core Analysis to Determine MEOR Requirements

Completed.

Task 1.4: $\quad$ Microbial Analyses of Cores

Completed.

Task 1.5: $\quad$ Laboratory Waterflooding Test of Live Cores

Completed. 


\section{Task 1.6 Acquisition of Baseline Data}

Acquisition of baseline data has been completed.

\section{Task 1.7: $\quad$ Analysis of Baseline Data}

The analysis of baseline data has been completed.

\section{Phase II: Implementation}

This phase involves initiation of nutrient injection and the analysis of results.

\section{Task 2.1 Design of Field Demonstration}

During the quarter, nutrient injection continued into ten injection wells and production response continued to be monitored in twenty producing wells. A significant response has recently been noted in the NBCU 34-2 No. 1. The response is believed to be the result of nutrient injection into the NBCU 34-7 No. 1 which began in July 1997.

\section{Task 2.2 Drill Three Additional Wells}

Completed

\section{Task 2.3 Reservoir Characterization}

Petrophysical studies of recovered core sample from the 3 newly drilled wells are still in progress.

\section{Task 2.5 Analysis of Results}

Monthly collection of produced fluids from the test and control wells in all patterns continued with the following tasks performed,

(1) Aliphatic profile (Gas chromatographic analysis),

(2) API gravity and absolute viscosity under reservoir temperature,

(3) $\mathrm{pH}$ of produced water,

(4) Surface tension (ST) of produced water (water-air),

(5) Interfacial tension (IFT) for produced oil-water system,

(6) Inorganic analyses (nitrate, phosphate, sulfate, sulfide, chloride, potassium, and hardness).

Production data on all wells in all patterns continues to be evaluated.

Gas samples are continuing to be collected from selected production wells and analyzed by gas chromatography using a Fisher Model No. 1200 Gas Partitioner. The results of analyses from two sets of samples are given in the accompanying tables. 
Gas Analyses of Samples collected March 5, 1998

\begin{tabular}{||c|c|c|c|c|c|c||}
\hline & $\begin{array}{c}\text { Carbon Dioxide } \\
(\boldsymbol{\%})\end{array}$ & $\begin{array}{c}\text { Ethane } \\
(\boldsymbol{\%})\end{array}$ & $\begin{array}{c}\text { Oxygen } \\
(\boldsymbol{\%})\end{array}$ & $\begin{array}{c}\text { Nitrogen } \\
(\boldsymbol{\%})\end{array}$ & $\begin{array}{c}\text { Propane } \\
(\boldsymbol{\%})\end{array}$ & $\begin{array}{c}\text { Methane } \\
(\boldsymbol{\%})\end{array}$ \\
\hline Field Gas 1 & 1.6 & 7.0 & 1.5 & 7.1 & 3.3 & 78.4 \\
\hline Field Gas 2 & 2.0 & 7.2 & 0.6 & 1.9 & 3.6 & 80.7 \\
\hline $35-141$ & 0.8 & 1.4 & 0.8 & 4.8 & $<0.7$ & 91.2 \\
\hline $35-142$ & 0.8 & 1.1 & 0.8 & 7.1 & $<0.7$ & 92.0 \\
\hline $34-8$ No. 1 & 0.3 & 8.6 & $<0.4$ & 1.4 & 3.9 & 82.2 \\
\hline $34-10$ No. 1 & 0.6 & 8.6 & 0,4 & 1.0 & 3.9 & 82.9 \\
\hline $34-7$ No. 2 & 0.6 & 8.6 & 0.4 & 1.4 & 3.9 & 85.2 \\
\hline $34-2$ No. 1 & 0.5 & 8.2 & 0.4 & 1.4 & 3.6 & 82.9 \\
\hline $34-6$ No. 3 & 0.6 & 8.0 & 0.8 & 4.0 & 3.6 & 80.7 \\
\hline Air & $<0.1$ & - & 19.3 & 77.1 & & - \\
\hline
\end{tabular}

Phosphate $0.19 \mathrm{pm}$ was found in the water sample from well 34-6 No. 3

Gas Analyses of Samples collected March 25, 1998

\begin{tabular}{||c|c|c|c|c|c|c||}
\hline \hline & $\begin{array}{c}\text { Carbon Dioxide } \\
(\boldsymbol{\%})\end{array}$ & $\begin{array}{c}\text { Ethane } \\
(\boldsymbol{\%})\end{array}$ & $\begin{array}{c}\text { Oxygen } \\
(\boldsymbol{\%})\end{array}$ & $\begin{array}{c}\text { Nitrogen } \\
(\boldsymbol{\%})\end{array}$ & $\begin{array}{c}\text { Propane } \\
(\boldsymbol{\%})\end{array}$ & $\begin{array}{c}\text { Methane } \\
(\boldsymbol{\%})\end{array}$ \\
\hline 2-5 No. 1 & 0.4 & 7.8 & 2.0 & 10.1 & 2.6 & 68.3 \\
\hline 2-5 No. 2 & 0.4 & 8.4 & 1.2 & 5.8 & 3.3 & 74.3 \\
\hline 2-13 No. 2 & 0.4 & 8.6 & 1.2 & 6.2 & 3.3 & 82.1 \\
\hline 34-2 No. 1 & 0.4 & 6.8 & 1.2 & 5.3 & 2.6 & 75.8 \\
\hline 34-6 No. 3 & 0.4 & 7.0 & 0.8 & 6.2 & 2.6 & 78.8 \\
\hline 3-8 No. 1 & 0.4 & 7.6 & 0.8 & 2.4 & 2.6 & 80.3 \\
\hline 34-7 No. 2 & 0.4 & 6.8 & 1.2 & 6.2 & 2.6 & 75.0 \\
\hline 34-10 No. 1 & 0.4 & 6.8 & 0.8 & 5.3 & 2.6 & 73.5 \\
\hline Air & $<0.2$ & - & 18.7 & 74.4 & - & - \\
\hline Air & $<0.2$ & - & 19.5 & 77.8 & - & - \\
\hline
\end{tabular}




\section{REFERENCES AND PUBLICATIONS}

\section{PLANS FOR NEXT QUARTER}

Monitoring of the influent of the injector wells and effluent from the production wells, including the three newly drilled wells, will continue.

Analyses of cores from newly drilled wells will continue and will include gas chromatographic analyses of residual oil for signs of microbial activity.

Analyses of gas from selected production wells will continue. 